\title{
Assessment of air pollution concentrations from brick kilns using an atmospheric dispersion model
}

\author{
T. Kanabkaew \& K. Buasing \\ Environmental Science Program, School of Engineering and Resources, \\ Walailak University, Thailand
}

\begin{abstract}
Brick manufacturing is traditionally a small-scale and improperly managed industry. Air pollutants, i.e. particulate matters (PM), carbon monoxide (CO) and sulfur dioxide $\left(\mathrm{SO}_{2}\right)$ were mainly emitted during the brick firing process. The area of Bang Pu, Nakhon Si Thammarat in southern Thailand was observed to have high numbers of the operating kilns. With substantial low height and conventionally unorganized industry, the nearby communities would be exposed to the adverse environmental and health impacts from local air pollutions. This paper was designed to develop a database of air pollutant emissions and to assess pollutant dispersion of $\mathrm{PM}_{10}, \mathrm{CO}$ and $\mathrm{SO}_{2}$ from brick kilns in Bang Pu, Nakhon $\mathrm{Si}$ Thammarat. Air pollution emission was estimated mainly using IPCC and USEPA guidelines. An AERMOD modeling system was used to simulate pollution dispersions. Results showed that emissions for each brick kiln including $\mathrm{PM}_{10}, \mathrm{CO}$ and $\mathrm{SO}_{2}$ were ranged between $0.0346-0.0751,1.3022-3.3603$ and $0.1736-0.4481$ $\mathrm{g} / \mathrm{s}$, respectively. For pollutant dispersions, simulated concentrations for a maximum 1-hour, 24-hour and annual averages were as follows: $\mathrm{PM}_{10}(13,1$ and $0.2 \mu \mathrm{g} / \mathrm{m}^{3}$, respectively); $\mathrm{CO}$ (487, 35 and $6 \mu \mathrm{g} / \mathrm{m}^{3}$, respectively); and $\mathrm{SO}_{2}(64,5$ and $1 \mu \mathrm{g} / \mathrm{m}^{3}$, respectively). The overall assessment showed that the concentrations of pollutants $\left(\mathrm{PM}_{10}, \mathrm{CO}\right.$ and $\left.\mathrm{SO}_{2}\right)$ met the National Ambient Air Quality Standards of Thailand. However, for long term health impact reduction, the appropriate prevention and mitigation measures should be implemented to control the concentrations of air pollutants from brick kilns in the area.
\end{abstract}

Keywords: air pollution, brick kilns, emission inventory, AERMOD. 


\section{Introduction}

Brick making in Thailand is traditionally a small scale or family industry which relies mainly on biomass fuel, i.e. firewood and rice husks $[1,2]$. The design of the brick kilns is rather simple - a traditional open-top updraft kiln. It has been seen, since 1990, particularly in the south of Thailand, that all industries were wood-based and open top brick kilns [2]. Until now, from our field survey in 2012 at Nakhon Si Thammarat, we found that wood was used as their only source of fuel for all kilns in the Bang Pu area. It appears that the kilns and technology have remained unchanged for the past decade and, subsequently, air pollutants would be emitted into the atmosphere and cause adverse impacts on the local communities and the environment.

Air pollutants, particularly particulate matters (PM), carbon monoxide (CO) and sulfur dioxide $\left(\mathrm{SO}_{2}\right)$ are products of the combustion processes [3, 4] and produced during the brick firing operations. PM and $\mathrm{CO}$ are mainly emitted from the incomplete combustions while $\mathrm{SO}_{2}$ is dependent on sulfur content in fuels [3]. These pollutants are generally included in the criteria pollutants of ambient air quality standards of national and international guidelines [5-7]. Exposures to these pollutants were observed to have caused increases in morbidity and mortality [8, 9]. Lack of emission control devices enhances the possibility of contact with the air pollutants.

At Bang Pu, Nakhon Si Thammarat (BP NST), Thailand as mentioned earlier, there were a total of 44 brick kilns in the area $(10 \mathrm{~km} \times 10 \mathrm{~km})$ and all kilns were wood-based fuel utilization. Without surface air quality monitoring stations in all receptors and limited information on air quality data in the area, impact assessment of local air pollutions on human health would be inaccessible. Dispersion models offer a solution to estimate air pollutant concentrations of the metrics in the model domains. AERMOD, the American Meteorological Society and US Environmental Protection Agency Regularly Model, is widely used for short-range (up to $50 \mathrm{~km}$.) air pollution dispersions [10-15].

This paper presents the development of an emission inventory and the impact assessment of air pollution concentrations from brick kilns using the AERMOD modeling system.

\section{Materials and methods}

\subsection{Study area}

The study area was set up to be $10 \mathrm{~km} \mathrm{x} 10 \mathrm{~km}$ covering the brick manufacturing in the BP NST (see Figure 1). There were around 44 brick kilns. BP NST is situated in the south of Thailand with a tropical climate with dry and wet seasons. Dry season is February to April with northeast (NE) monsoon. Wet season can be classified into 2 periods: May to October with southwest (SW) monsoon and November to January with NE monsoon [16]. As of 2012 record, the annual average temperature for BP NST is $27.3^{\circ} \mathrm{C}$. Average relative humidity is $83 \%$ and annual rainfall is $2,870 \mathrm{~mm}$ [16]. 


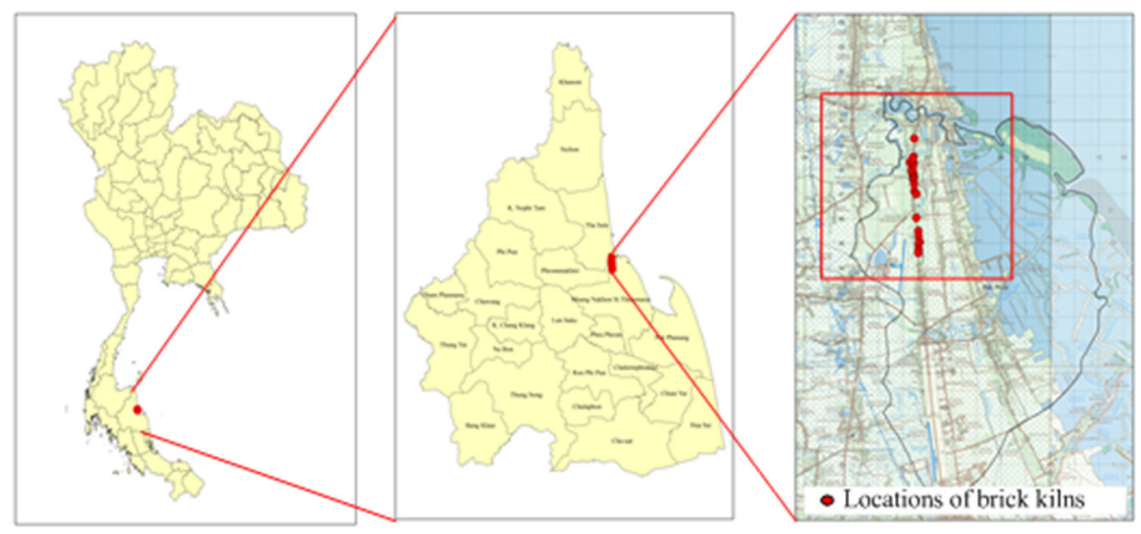

Figure 1: Study area.

All brick kilns found in BP NST were traditionally open top-updraft kilns (see Figure 2). This type is a simple technology with firewood consumption that is passed from one generation to another. As seen in Figure 2(a), the open top kilns were designed to be equipped with 2 layers of roof that allowed air flow from the kilns to the atmosphere. From the field survey, the height of kilns was around 2$5 \mathrm{~m}$. The width and length were also varied depending on the desired production yield. Maximum width and length of the kilns in BP NST were $7 \mathrm{~m}$ and $14 \mathrm{~m}$, respectively. The sketch in Figure 2(b) shows a clearer picture of the kilns with 2 main components: loading and unloading door, and fire tunnels. Green bricks were fed inside the kiln and firewood was burnt in the fire tunnels along the wall. The firing processes in tunnel kilns were started by brick drying, preheating, firing and cooling which were continuously and simultaneously processed [1]. Time spent for one cycle/batch of brick firing processes was around 4-5 days before starting the next cycle.

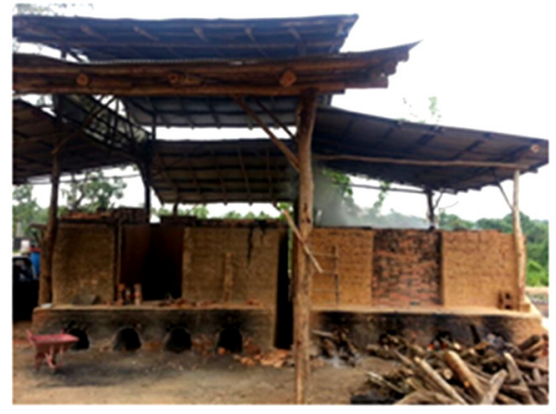

(a)

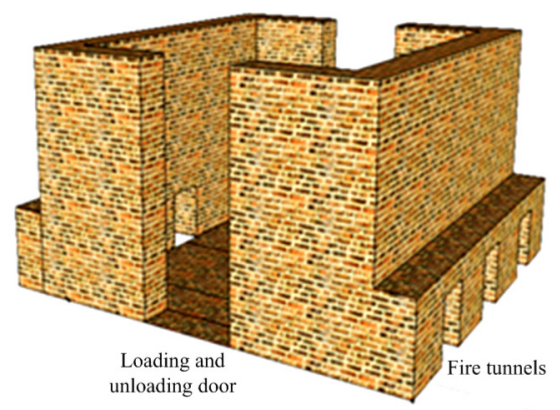

(b)

Figure 2: Traditional open top-updraft kiln: (a) photograph and (b) sketch. 


\subsection{Research design}

The methodology framework of this study is indicated in Figure 3. Emission estimation was the foremost step to obtain the emissions of pollutants for the three selected species including $\mathrm{PM}_{10}, \mathrm{CO}$ and $\mathrm{SO}_{2}$. The next step, AERMOD preprocessors, AERMET and AERMAP were run to produce meteorological fields and terrain data. Finally, AERMOD, the core module, was then compiled from the emission data (loading rates), stack data, meteorological data and terrain data to produce the pollutant concentrations in the specified $10 \mathrm{~km} \mathrm{x} 10 \mathrm{~km}$ modelling domains in BP NST.

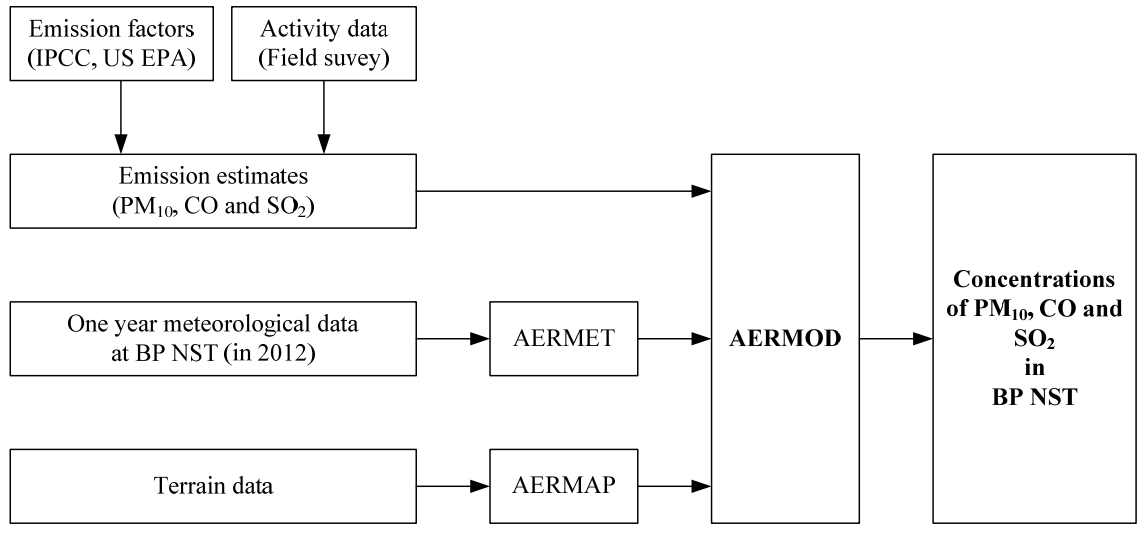

Figure 3: Framework of methodology.

\subsubsection{Emission estimate}

There has been a lack of emission monitoring at the stacks/kilns since the monitoring requires a large amount of financial support. Thus, estimated emission data is required for this study. Emissions of air pollutants are basically calculated using eqn (1) where $i$ is type of pollutant; $\mathrm{Em}_{\mathrm{i}}$ is emission of pollutant $\mathrm{i}$ (mass per time); $A R_{i}$ is activity rate of data related emission of pollutant $i$ (activity unit per time); $\mathrm{EF}_{\mathrm{i}}$ is emission factor for pollutant $\mathrm{i}$ (mass per activity unit) [17]. Types of pollutants covered by the emission estimates are $\mathrm{PM}_{10}, \mathrm{CO}$ and $\mathrm{SO}_{2}$.

$$
\mathrm{Em}_{\mathrm{i}}=\Sigma\left(\mathrm{AR}_{\mathrm{i}} \times \mathrm{EF}_{\mathrm{i}}\right)
$$

2.2.1.1 Activity rate of data Activity rate of data refers to the amount of fired bricks produced or firewood utilization per unit of time. These data were collected during the field survey of all brick kilns in the study area. Tonnes of fired bricks produced were used for PM10 estimates while tonnes of firewood utilization were then converted to the energy content-based unit that is in TJ and used for $\mathrm{CO}$ and SO2 estimates.

2.2.1.2 Emission factors Emission factors (EF) are expressed in the unit of $\mathrm{kg}$ /tonne for $\mathrm{PM}_{10}$ and $\mathrm{kg} / \mathrm{TJ}$ for $\mathrm{CO}$ and $\mathrm{SO}_{2}$, respectively. Details of emission 
factors used for brick kiln emission estimation is indicated in Table 1. EFs were mainly gathered from the US EPA [18] and IPCC [19] emission inventory guidelines. EFs for $\mathrm{PM}_{10}$ and $\mathrm{CO}$ are normally collected based on source samplings for various types of fuels and technologies of brick kilns [18, 19]. For $\mathrm{SO}_{2}$, EF is mainly derived from sulfur content of the fuels. Thus, for wood-based kilns, $\mathrm{SO}_{2}$ was considered to be rather low $(267 \mathrm{~kg} / \mathrm{TJ})$ when compared to coalbased kilns $(4,540 \mathrm{~kg} / \mathrm{TJ})$ [21].

Table 1: Emission factors (EF) used in brick kiln emission estimation.

\begin{tabular}{|c|c|}
\hline Pollutants & EF for Firewood $(\mathrm{kg} / \mathrm{TJ})$ \\
\hline $\mathrm{PM}_{10}{ }^{\mathrm{a}}$ & $0.63 \mathrm{~kg} / \mathrm{tonne}$ \\
\hline $\mathrm{CO}$ & 2,000 \\
\hline $\mathrm{SO}_{2}$ & 267 \\
\hline
\end{tabular}

${ }^{\mathrm{a}} \mathrm{kg}$ per tonne of fired brick produced, US EPA [18]. Other EFs are from IPCC [19].

\subsubsection{AERMOD modelling processes}

The model domain was set up to be the Cartesian 50 x 50 grids of $200 \mathrm{~m}$. (10 km $\mathrm{x} 10 \mathrm{~km}$ ) covering all brick kilns in BP NST. AERMOD, the core model, is designed based on the Gaussian equation to simulate pollutant concentrations and dispersions from point, area and volume sources. AERMOD is proposed for shortrange domain $(50 \mathrm{~km} \times 50 \mathrm{~km})[13,14,20]$. The reason is that the model assumes conservation of mass from sources. In other words, no chemical reaction takes place in the model simulation. Thus, within short-range, the atmospheric reaction would be less and considered insignificant [12]. AERMOD comprised two main pre-processors: AERMET and AERMAP.

2.2.2.1 AERMET AERMET is the meteorological pre-processor. AERMET was developed to produce the suitable format of meteorological data for AERMOD [20]. Outputs from the AERMET module consisted of surface meteoroidal data and upper air data. Surface meteorological data in 2012 were mainly taken from the Thai Meteorological Department (TMD), Thailand and the global data network at University of Wyoming for Nakhon Si Thammarat station. Upper air data were taken from the National Oceanic and Atmospheric Administration (NOAA) at http://esrl.noaa.gov/raobs/.

2.2.2.2 AERMAP AERMAP is a terrain pre-processor. AERMAP processes available Digital Elevation Data (DEM) and creates a file suitable for use within AERMOD [20]. DEM files for the study area were obtained from the global data archive at ASTER GDEM (http://gdem.ersdac.jspacesystems.or.jp/). The DEM provides $30 \mathrm{~m}$ in resolution to create the elevation and hill height for stacks and receptors in the modeling system. 


\section{Results and discussion}

\subsection{Emission estimate}

Emission inventory plays an important role in air quality management programs and serves as the necessary information for model simulations. To assess the impacts of brick kiln emissions on the local air quality, the updated local database was conducted. Lack of detailed emission data would increase uncertainty in the modeling study.

In this section, brick kiln emissions were estimated in BP NST where a large quantity of bricks is produced weekly and simultaneously throughout the year. The emission estimates were prepared for the base year of 2012. Species of air pollutants included in this study were $\mathrm{PM}_{10}, \mathrm{CO}$ and $\mathrm{SO}_{2}$. Estimated emissions are shown in Table 2.

Table 2: Total emission estimates for brick kilns in BP NST in 2012.

\begin{tabular}{|c|c|c|c|}
\hline \multirow{2}{*}{ Source } & \multicolumn{3}{|c|}{ Emission estimate $(\mathrm{Mg} /$ year $)$} \\
\cline { 2 - 4 } & $\mathrm{PM}_{10}$ & $\mathrm{CO}$ & $\mathrm{SO}_{2}$ \\
\hline Brick kilns & 71 & 2,720 & 363 \\
\hline
\end{tabular}

Emissions of brick kilns in BP NST including $\mathrm{PM}_{10}, \mathrm{CO}$ and $\mathrm{SO}_{2}$ were 71 ; 2,720 and $363 \mathrm{Mg} /$ year, respectively. We found a rather high estimation of CO. The reason is that EF of CO for wood-based kilns was high since it tended to have incomplete combustion $[18,19]$. To include the emission estimates into AERMOD modeling system, annual estimation data were converted to loading rates $(\mathrm{g} / \mathrm{s})$ for each pollutant of all 44 kilns. Thus, $\mathrm{PM}_{10}, \mathrm{CO}$ and $\mathrm{SO}_{2}$ loading rates ranged between $0.0346-0.0751,1.3022-3.3603$ and $0.1736-0.4481 \mathrm{~g} / \mathrm{s}$, respectively.

Emission estimates could pose a large uncertainty in terms of, mainly, the activity rates of data and emission factors applied for the calculation [23, 24]. Comparing the estimated emissions with other studies in the same domain was proposed for the uncertainty assessment [23]. However, in this study, the activity rates of data were gathered by field survey for the key parameters, i.e. types of fuel utilization, tonnes of bricks produced, control devices and periods of firing processes, and the relevant data, i.e. stack parameters (temperature, velocity, dimensions and coordinates). For emission factors, we applied the values from the scientific publications, i.e. IPCC [19] and US EPA [18] which were well documented and mentioned globally. With the small domain and local sources of air pollutants, comparison with other studies would be unattainable. Based on the data and processes of calculation, the uncertainty in our estimated emissions would be explainable and acceptable for further modeling study.

\subsection{Modelling of $\mathrm{PM}_{10}, \mathrm{CO}$ and $\mathrm{SO}_{2}$}

AERMOD modelling system was applied to simulate concentrations and dispersions of $\mathrm{PM}_{10}, \mathrm{CO}$ and $\mathrm{SO}_{2}$ over BP NST in 2012. Maximum concentrations 
for 1-hour, 24-hour and annual averages are shown in Table 3 and can be summarized as follows: $\left.\mathrm{PM}_{10}\right) 13,1$ and $0.2 \mu \mathrm{g} / \mathrm{m}^{3}$, respectively(; $\mathrm{CO}(487,35$ and $6 \mu \mathrm{g} / \mathrm{m}^{3}$, respectively); and $\mathrm{SO}_{2}\left(64,5\right.$ and $1 \mu \mathrm{g} / \mathrm{m}^{3}$, respectively). The simulated concentrations for $\mathrm{PM}_{10}, \mathrm{CO}$ and $\mathrm{SO}_{2}$ were well below the NAAQS of Thailand and WHO air quality guidelines (see also Table 3 ).

Table 3: Summary of AERMOD modelling results.

\begin{tabular}{|l|c|c|c|}
\hline \multirow{2}{*}{ Pollutant } & \multicolumn{3}{|c|}{ Maximum concentration $\left(\mu \mathrm{g} / \mathrm{m}^{3}\right)$} \\
\cline { 2 - 4 } & 1-hour average & 24-hour average & Annual average \\
\hline PM $_{10}$ : & & & \\
- Simulation & 13 & 1 & 0.2 \\
- NAAQS & n.s. & 120 & 50 \\
- WHO & n.s. & 50 & 20 \\
\hline CO: & & & \\
- Simulation & 487 & 35 & 6 \\
- NAAQS & 34,200 & n.s. & n.s. \\
- WHO & 30,000 & n.s. & \\
\hline SO : & & & 1 \\
- Simulation & 64 & 5 & 100 \\
- NAAQS & 780 & 300 & n.s. \\
- WHO & n.s. & 20 & \\
\hline
\end{tabular}

NAAQS (National Ambient Air Quality Standards in Thailand) [5]; WHO (World Health Organization Air Quality Guidelines) [7, 22]; n.s. = not specified.

It is interesting to highlight that the maximum simulated $\mathrm{SO}_{2}$ concentrations accounted for around $8 \%$ of standard value for 1-hour average (NAAQS) and around $25 \%$ of standard value for 24-hour average (WHO). Exposures to $\mathrm{SO}_{2}$ (for 24 hours) as the low concentrations as $5-10 \mu \mathrm{g} / \mathrm{m}^{3}$, were significantly associated with adverse health impacts and daily mortality [7].

For $\mathrm{PM}_{10}$, maximum simulated concentration for 1-hour average was $13 \mu \mathrm{g} / \mathrm{m}^{3}$. It was the lack of data reported the known health impacts for 1-hour exposures since the adverse health impacts of $\mathrm{PM}_{10}$ were mainly associated with the long term [7]. Simulated $\mathrm{PM}_{10}$ concentrations for 24-hour and annual averages in this study were rather low when compared with NAAQS and WHO guidelines.

Exposures to $\mathrm{CO}$ would contribute to adverse impacts in a very short term (15 minutes, 30 minutes, 1 hour and 8 hours) [22]. Simulated CO concentrations for 1-hour, 24-hour and annual averages were close to $\mathrm{CO}$ backgrounds which range between 60 and $140 \mu \mathrm{g} / \mathrm{m}^{3}$ [22] and rather low comparing to the standards.

In terms of spatial analysis, the dispersion pattern of the pollutant is shown for $\mathrm{SO}_{2}$ as indicated in Figure 4. The annual prevailing wind directions (Figure 4(d)) were NE and SW with the dominant wind speeds of 2-6 m/s (average wind speed 
was $2 \mathrm{~m} / \mathrm{s}$ ). Since the kilns were located along $5 \mathrm{~km}$ both sides of the road in BP NST, the expansion of the plume would not be very consistent with wind directions. This is due to added up concentrations from one kiln to others. Maximum concentrations of pollutants $\left(\mathrm{PM}_{10}, \mathrm{CO}\right.$ and $\left.\mathrm{SO}_{2}\right)$ were mainly found at the locations near the sources.
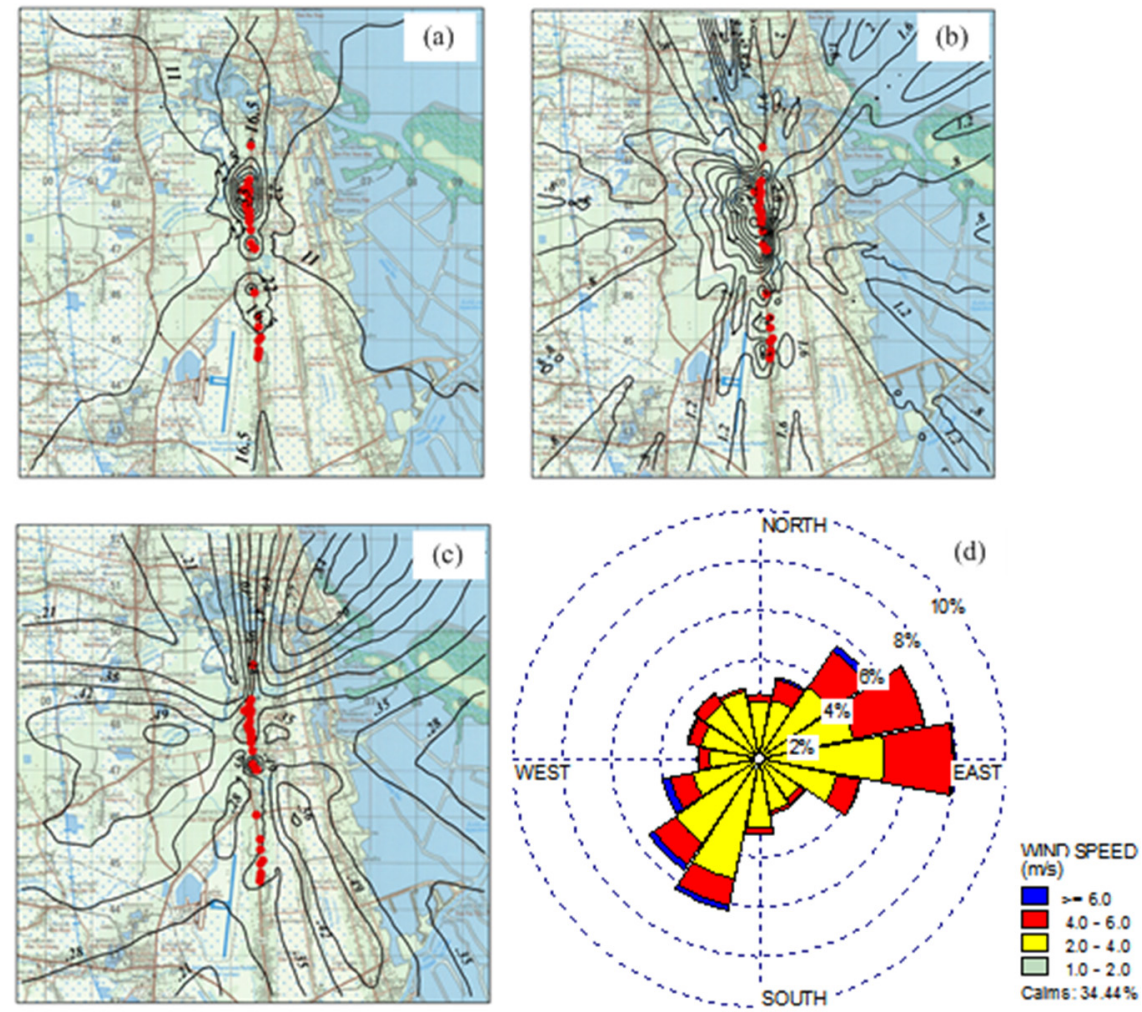

Figure 4: Dispersions of simulated $\mathrm{SO}_{2}$ concentrations $\left(\mu \mathrm{g} / \mathrm{m}^{3}\right)$ from brick kilns in BP NST (10 km x $10 \mathrm{~km}$ ) for (a) 1-hour average, (b) 24-hour average, (c) annual average and (d) the wind rose diagram in 2012.

\subsection{Discussion: toward local air quality and health impact assessment}

Although the preliminary simulated pollutants from 44 brick kilns in this study were well below the NAAQS and WHO air quality guidelines, maximum 24-hour $\mathrm{SO}_{2}$ concentration $\left(5 \mu \mathrm{g} / \mathrm{m}^{3}\right)$ was close to threshold values $\left(5-10 \mu \mathrm{g} / \mathrm{m}^{3}\right)$ [7]. Locations of maximum simulated concentrations were found to be near the sources. With the simple design, low height and increasing demand of bricks, but without the control device, local workers and communities were classified as a risk group for adverse health impacts of air pollutions. 
However, this study used estimated emissions for modelling input that could be a source of uncertainty. Future investigation should focus on emission monitoring to obtain the actual emissions. Modelling applications for different years would be another suggestion to produce the concrete dispersion pattern.

\section{Conclusions}

There were 44 bricks kilns located in the area of $10 \mathrm{~km} \times 10 \mathrm{~km}$ BP NST. All kilns were simply designed with open top-updraft type with fuel wood utilization. Estimated emissions for $\mathrm{PM}_{10}, \mathrm{CO}$ and $\mathrm{SO}_{2}$ in 2012 were $71 ; 2,720$ and 363 $\mathrm{Mg}$ /year. For AERMOD modelling application, simulated maximum concentrations for 1-hour, 24-hour and annual average were as follows: $\left.\mathrm{PM}_{10}\right) 13$, 1 and $0.2 \mu \mathrm{g} / \mathrm{m}^{3}$, respectively(; $\mathrm{CO}\left(487,35\right.$ and $6 \mu \mathrm{g} / \mathrm{m}^{3}$, respectively); and $\mathrm{SO}_{2}$ (64, 5 and $1 \mu \mathrm{g} / \mathrm{m}^{3}$, respectively). All simulated concentrations were well below the NAAQS of Thailand and WHO air quality guidelines.

\section{Acknowledgements}

The authors would like to thank Thai Meteorological Department and University of Wyoming for meteorological data and also ASTER GDEM for terrain data.

\section{References}

[1] Prasertsan, S., Theppaya, T., Prateepchaikul, G. \& Kirirat, K., Development of an energy-efficient brick kiln. International Journal of Energy Research, 21(5), pp. 1363-1383, 1997.

[2] Joseph, S., McGarry, B., Sajjakulnukit, B. \& Sopchokchai, O., A study of brick production in Thailand. TDRI Quarterly Review, 5(2), pp. 11-15, 1990.

[3] Seinfeld, J.H. \& Pandis, S.N., Atmospheric Chemistry and Physics: From Air Pollution to Climate Change, John Wiley \& Sons: Chichester, pp. 50121, 2006.

[4] Bai, Y., Thompson, G.E. \& Martinez-Ramirez, S., Effects of $\mathrm{NO}_{2}$ on oxidation mechanisms of atmospheric pollutant SO2 over Baumberger sandstone. Building and Environment, 41(4), pp. 486-491, 2006.

[5] National Ambient Air Quality Standards (NAAQS) of Thailand; Pollution Control Department, http://www.pcd.go.th/info_serv/reg_std_airsnd01.html.

[6] National Ambient Air Quality Standards (NAAQS) of United State; U.S. Environmental Protection Agency, http://epa.gov/ttn/naaqs/.

[7] WHO. Air Quality Guidelines for Particulate Matter, Ozone, Nitrogen Dioxide and Sulfur Dioxide: Summary of Risk Assessment. World Health Organization: Geneva, 2006.

[8] Backes, C.H, Nelin, T., Gorr, M.W. \& Wold, L.E., Early life exposure to air pollution: How bad is it? Toxicology Letters, 216(1), pp. 47-53, 2013. 
[9] Neupane, B., Jerrett, M., Burnett, R.T., Marrie, T., Arain, A., and Loeb, M., Long-term exposure to ambient air pollution and risk of hospitalization with community-acquired pneumonia in older adults. American Journal of Respiratory and Critical Care Medicine, 181(1), pp. 47-53, 2010.

[10] Seangkiatiyuth, K., Surapipith, V., Tantrakarnapa, K. \& Lothongkum, A.W. Application of the AERMOD modeling system for environmental impact assessment of $\mathrm{NO}_{2}$ emissions from a cement complex. Journal of Environmental Sciences, 23(6), pp. 931-940, 2011.

[11] Afzali, A., Rashid M., Noorhafizah K. \& Ammar M.R. Evaluating human exposure to emission from incineration plant using AERMOD dispersion modeling. Iranian Journal of Public Health, 43(3), 25-33.

[12] Gibson, M.D., Kundu, S. \& Satish, M., Dispersion model evaluation of $\mathrm{PM}_{2.5}, \mathrm{NO}_{\mathrm{X}}$ and $\mathrm{SO}_{2}$ from point and major line sources in Nova Scotia, Canada using AERMOD Gaussian plume air dispersion model. Atmospheric Pollution Research, 4(2), pp. 157-167, 2013.

[13] Cimorelli, A.J., Perry, S.G., Venkatram, A., Weil, J.C., Paine, R.J., Wilson, R.B., Lee, R.F., Peters, W.D. \& Brode, R.W., AERMOD: a dispersion model for industrial source applications. Part I: general model formulation and boundary layer characterization. Journal of Applied Meteorology, 44(5), pp. 682-693, 2005.

[14] Perry, S.G., Cimorelli, A.J., Paine, R.J., Brode, R.W., Weil, J.C., Venkatram, A., Wilson, R.B., Lee, R.F. \& Peters, W.D., AERMOD: a dispersion model for industrial source applications. Part II: model performance against 17 field study databases. Journal of Applied Meteorology, 44(5), pp. 694-708, 2005.

[15] Le, H.A. \& Kim Oanh, N.T. Integrated assessment of brick kiln emission impacts on air quality. Environmental Monitoring and Assessment, 171(14), pp. 381-394, 2010.

[16] Weather and climate characteristics of Nakhon Si Thammarat (in Thai), http://www.nakhonsithammarat.go.th/web_52/air.php.

[17] Shrestha R.M., Kim Oanh N.T., Shrestha R.P., Rupakheti M., Rajbhandari S., Permadi D.A., Kanabkaew, T. \& Iyngararasan, M., Atmospheric Brown Clouds (ABC) Emission Inventory Manual. United Nations Environment Programme: Nairobi, 2013.

[18] Brick and structural clay product manufacturing; compilation of air pollution emission factor, www.epa.gov/ttn/chief/ap42/ch11/final/ c11s03.pdf.

[19] IPCC. Revised IPCC Guidelines for national Greenhouse Gas Inventories: Reference Manual, Volumes I, II, and III. Intergovernmental Panel on Climate Change: Geneva, 1996.

[20] USEPA. AERMOD: Description of Model Formulation. US Environmental Protection Agency: North Carolina, 2004.

[21] Iqbal, A. \& Kim Oanh, N.T., Assessment of acid deposition over Dhaka division using CAMx-MM5 modeling system. Atmospheric Pollution Research, 2(4), pp. 452-462, 2011. 
[22] Carbon monoxide, World Health Organization Air Quality Guidelines, http://www.euro.who.int/_data/assets/pdf_file/0020/123059/AQG2ndEd_ 5 carbonmonoxide.PDF.

[23] Zhao, Y., Nielsen, C.P., Lei, Y., McElroy, M.B. \& Hao, J., Quantifying the uncertainties of a bottom-up emission inventory of anthropogenic atmospheric pollutants in China. Atmospheric Chemistry and Physics, 11(5), pp. 2295-2308, 2011.

[24] Aardennem, J-V., \& Pulles, T., Uncertainty in emission inventories: What do we mean and how could we assess it? Proc. of the 11th International Emission Inventory Conference, US EPA: North Carolina, pp. 1-11, 2002. 